\title{
HARVEST-RELATED EDGE EFFECTS ON PREY AVAILABILITY AND FORAGING OF HOODED WARBLERS IN A BOTTOMLAND HARDWOOD FOREST
}

\author{
John C. KILGO ${ }^{1}$ \\ U.S. Forest Service Southern Research Station, P.O. Box 700, New Ellenton, SC 29809
}

\begin{abstract}
The effects of harvest-created canopy gaps in bottomland hardwood forests on arthropod abundance and, hence, the foraging ecology of birds are poorly understood. I predicted that arthropod abundance would be high near edges of group-selection harvest gaps and lower in the surrounding forest, and that male Hooded Warblers (Wilsonia citrina) foraging near gaps would find more prey per unit time than those foraging in the surrounding forest. In fact, arthropod abundance was greater $>100 \mathrm{~m}$ from a gap edge than at $0-30 \mathrm{~m}$ or 30-100 m from an edge, due to their abundance on switchcane (Arundinaria gigantea); arthropods did not differ in abundance among distances from gaps on oaks (Quercus spp.) or red maple (Acer rubrum). Similarly, Hooded Warbler foraging attack rates were not higher near gap edges: when foraging for fledglings, attack rate did not differ among distances from gaps, but when foraging for themselves, attack rates actually were lower $0-30 \mathrm{~m}$ from gap edges than $30-100 \mathrm{~m}$ or $>100 \mathrm{~m}$ from a gap edge. Foraging attack rate was positively associated with arthropod abundance. Hooded Warblers apparently encountered fewer prey and presumably foraged less efficiently where arthropods were least abundant, i.e., near gaps. That attack rates among birds foraging for fledglings were not affected by distance from gap (and hence arthropod abundance) suggests that prey availability may not be limiting at any location across the forest, despite the depressing effects of gaps on arthropod abundance.
\end{abstract}

Key words: arthropod, bottomland hardwoods, canopy gap, foraging, Hooded Warbler, timber harvest, Wilsonia citrina.

Efectos de Borde Relacionados con la Cosecha Forestal sobre la Disponibilidad de Presas y el Forrajeo de Wilsonia citrina en un Bosque Leñoso Ribereño

Resumen. El efecto de la creación de claros en el dosel por la cosecha de árboles en bosques leñosos ribereños sobre la abundancia de artrópodos y por lo tanto sobre la ecología de forrajeo de las aves es poco entendido. En este estudio, predije que la abundancia de artrópodos sería mayor cerca de los bordes de claros producidos por tala selectiva en grupo y menor en el bosque circundante, y que los machos de Wilsonia citrina que forrajean cerca de los claros encontrarían más presas por unidad de tiempo que aquellos que forrajean en el bosque circundante. De hecho, la abundancia de artrópodos fue mayor a más de $100 \mathrm{~m}$ del borde de los claros que entre 0 y $30 \mathrm{~m}$ o entre 30 y $100 \mathrm{~m}$ desde un borde, debido a la abundancia de los artrópodos sobre Arundinaria gigantea. La abundancia de artrópodos sobre Quercus spp o Acer rubrum no fue diferente entre distintas categorías de distancia desde los claros. De manera similar, las tasas de ataque de forrajeo de W. citrina no fueron mayores cerca de los bordes de los claros: cuando se encontraban forrajeando para los polluelos, las tasas de ataque no fueron diferentes entre las distancias desde los claros, pero cuando se encontraban forrajeando para ellos mismos, las tasas de ataque fueron menores entre 0 y $30 \mathrm{~m}$ desde el borde de un claro a más de $30 \mathrm{~m}$ de un borde de un claro. La tasa de ataques de forrajeo se relacionó positivamente con la abundancia de artrópodos. Aparentemente, $W$. citrina encontró menos presas y posiblemente forrajeó de una manera menos eficiente donde los artrópodos eran menos abundantes, i.e., cerca de los claros. El hecho de que la tasa de ataque por parte de individuos que estaban forrajeando para sus polluelos no fuera afectada por la distancia a los bordes (y por lo tanto por la abundancia de artrópodos) sugiere que la disponibilidad de presas no parece ser limitante en ningún lugar del bosque, a pesar del efecto negativo de los claros sobre la abundancia de artrópodos.

Manuscript received 22 July 2004; accepted 20 April 2005.

${ }^{1}$ E-mail: jkilgo@fs.fed.us 


\section{INTRODUCTION}

In the southeastern United States, bottomland hardwood forests serve as important stopover (Kilgo et al. 1999) and breeding habitat (Pashley and Barrow 1993, Hodges and Krementz 1996, Kilgo et al. 1998, Sallabanks et al. 2000) for migratory songbirds. These forests also are important sources of hardwood lumber in the region (Wigley and Roberts 1997). Few studies have investigated bird response to timber harvest in bottomland forests (Hamel 1989, Mitchell and Lancia 1990, Harrison and Kilgo 2004), though several recent studies have examined various aspects of bird response to group-selection timber harvest, including breeding community dynamics (Moorman and Guynn 2001), nesting success (Moorman et al. 2002), and fall migrant use (Kilgo et al. 1999). Still, little is known about the impacts of such harvest-created openings on the foraging ecology of birds.

Canopy gaps can be an important habitat component for forest birds (Schemske and Brokaw 1981, Wunderle et al. 1987), and many species apparently are attracted to gap habitats (Smith and Dallman 1996). Natural canopy gaps have been reported to support greater numbers of birds than surrounding forest in both temperate (Blake and Hoppes 1986, Martin and Karr 1986) and tropical regions (Levey 1988). Harvest-created gaps may play a similar role; those in a South Carolina bottomland forest had a greater abundance of forest birds than the surrounding forest during both the breeding season (Moorman and Guynn 2001) and fall migration (Kilgo et al. 1999), although Germaine et al. (1997) reported avoidance of gaps by several species in a northern hardwood forest. Exactly which aspects of gaps render them attractive to birds is unclear, but some researchers have suggested that birds may track the greater resources often available in gaps (Martin and Karr 1986, Levey 1988). For example, Levey (1988) documented greater fruit availability in gaps than surrounding forest. Research on insect abundance in gap habitat relative to surrounding forest indicates a more variable pattern (Shure and Phillips 1991, Norwood et al. 1995, Gorham et al. 1996), probably due to the tremendous diversity of this taxonomic group and to the variable settings in which it has been studied.

Arthropods are the primary food of most species of forest birds during the breeding season.
My objective was to assess the impacts of group-selection harvest gaps on the availability of prey and, in turn, foraging efficiency of Hooded Warblers (Wilsonia citrina). Because some arthropods are particularly adapted to exploit disturbed patches (Schowalter 1985), some prefer plants growing in sunlight (White 1984) and some are positively associated with edge (Rodenhouse et al. 1997), I predicted that arthropod abundance would be high near gap edges and lower in the surrounding forest. Further, as foraging efficiency of birds should be greatest where arthropod prey is most abundant (Hutto 1990, Lovette and Holmes 1995), I predicted that birds foraging near gaps would find more prey per unit time than those foraging in the surrounding forest. I evaluated this prediction using the Hooded Warbler because it is a forest interior species that uses canopy gaps (Moorman and Guynn 2001), it is insectivorous (Evans Ogden and Stutchbury 1994), it nests and forages in the understory (Kilgo et al. 1996, Buffington et al. 2000, Moorman et al. 2002), and it is abundant on the study site. Hooded Warblers on the study site forage primarily by hovering or gleaning insects from leaves and stems, with $>90 \%$ of foraging attacks being directed at these substrates (Buffington et al. 2000), and their most frequent food items are coleopterans, lepidopterans, araneans, and homopterans (Bowen 2004).

\section{STUDY AREA}

The study was conducted on the U.S. Department of Energy's Savannah River Site (SRS), a 78 000-ha National Environmental Research Park in Aiken, Barnwell, and Allendale Counties, South Carolina. The SRS is in the Upper Coastal Plain physiographic province. Uplands on the SRS are predominantly loblolly (Pinus taeda) and longleaf pine (P. palustris) forest and lowlands are predominantly bottomland hardwood forest. This research was part of a larger study investigating canopy gap dynamics in group-selection timber harvests in bottomland hardwoods. The study site was a 120-ha stand of second growth bottomland hardwoods along the eastern edge of the Savannah River floodplain. The stand was logged ca. 1900 but had experienced little subsequent anthropogenic disturbance (Workman and McLeod 1990). The canopy was 22-28 $\mathrm{m}$ in height and was dominated by bottomland oaks (cherrybark, Quercus 
falcata var. paegodifolia; swamp chestnut, $Q$. michauxii; overcup, $Q$. lyrata; white, $Q$. alba; willow, $Q$. phellos; laurel, $Q$. laurifolia), sweetgum (Liquidambar styraciflua), green ash (Fraxinus pensylvanica), red maple (Acer rubrum), and elms (winged, Ulmus alata; and American, $U$. americana), with dwarf palmetto (Sabal minor) and switchcane (Arundinaria gigantea) in the understory.

Thirty-six group-selection cuts (hereafter, gaps) were harvested during December 1994. The experimental gaps included six replicates of six sizes, ranging from $0.02-0.5$ ha $(7-40 \mathrm{~m}$ in radius). These sizes fall within the range of commercial group-selection prescriptions and are comparable to the size of naturally occurring windthrow gaps (Collins and Battaglia 2002). Gap vegetation was dominated by herbaceous species, dwarf palmetto, blackberry (Rubus spp.), and seedlings and saplings of regenerating overstory species, mainly sweetgum and loblolly pine. There were few differences in vegetation composition among the gaps (Castleberry et al. 2000), but vegetation structure and height increased through the three years of the study (Moorman and Guynn 2001), the latter ranging from approximately $1-3 \mathrm{~m}$.

\section{METHODS}

\section{ARTHROPOD SAMPLING}

To assess the influence of gaps on arthropod prey potentially available to Hooded Warblers, I compared foliage-dwelling arthropod abundance on three plant species groups in the forest surrounding gaps of three sizes $(0.06,0.13$, and $0.50 \mathrm{ha})$ at three distance intervals from gap edges $(0-30 \mathrm{~m}, 30-100 \mathrm{~m}$, and $>100 \mathrm{~m})$ during June 1998. These sizes included three of the four largest of the six gap sizes in the study and were therefore most likely to produce edge effects that might be detectable in the surrounding forest. The three plant species groups were oaks (white oak and swamp chestnut oak), red maple, and switchcane. These groups were selected because they were deemed representative of substrates on which Hooded Warblers commonly forage at this site (pers. obs.). During another study that collected $>1000$ observations of Hooded Warblers foraging at the study site, 34 substrates were identified (L. T. Bowen, N.C. State University, unpubl. data). Among the 34 substrates, oaks ranked first, red maple ranked fourth, and switchcane ranked sixth in frequency of use. I collected two samples from different individuals of each species within each distance interval around two replicate gaps of each size, resulting in 108 samples ( 3 gap sizes $\times 3$ distance intervals $\times 3$ species groups $\times 2$ replicate gaps $\times 2$ samples).

I sampled arthropod abundance using foliage clipping, a technique that has been used widely in avian foraging studies (Cooper and Whitmore 1990), particularly when caterpillars are important food items, as they are for Hooded Warblers (Bowen 2004). Despite the facts that sample sizes tend to be small (Majer et al. 1990) and highly mobile arthropods (a group of less interest for this study) are not as effectively sampled, foliage clipping is the preferred method for sampling mid-canopy sessile arthropods (Cooper and Whitmore 1990). Each foliage sample consisted of 25 branch tips (i.e., the terminal 10-15 $\mathrm{cm}$ of stem, including the terminal leaf cluster; total 2700 branch tips in the 108 samples) collected as uniformly as possible between ground level and a height of approximately $9.1 \mathrm{~m}$, a height range that encompassed most of the foraging space of Hooded Warblers (pers. obs.). Buffington et al. (2000) reported that mean foraging height for Hooded Warblers on SRS was $6.4 \mathrm{~m}$. Workers collected samples using a 9.1-m pole pruner. Mounted beneath the pruning head was a butterfly net, into which a plastic garbage bag was placed to collect clipped branches. Sample bags were placed in a freezer for $24 \mathrm{hr}$ to kill all arthropods. Samples were then sorted to collect arthropods, which were identified to order. The vegetation was dried for $48 \mathrm{hr}$ at $40^{\circ} \mathrm{C}$ and weighed.

\section{FORAGING OBSERVATIONS}

I used temporal attack rate as an index of foraging efficiency (Hutto 1990, Lovette and Holmes 1995), acknowledging that it actually reflects searching success rather than true foraging success (Robinson and Holmes 1984). Three observers conducted foraging observations of male Hooded Warblers during the breeding season, from early May through late June, 1996-1998. All observations were made during the morning, within five hours after sunrise. $\mathrm{Ob}-$ servers traversed the study site searching for actively foraging birds; individuals primarily singing, preening, or loafing were not included. Most birds were individually identifiable due to the 
color banding, territory mapping, and nest monitoring efforts of concurrent studies (Moorman and Guynn 2001, Moorman et al. 2002; JCK, unpubl. data). Upon locating a bird, the observer recorded data on a microcassette recorder until visual contact was lost. Data recorded included the duration of each observation, the number of attacks directed at prey, the distance to $(0-30 \mathrm{~m}$, $30-100 \mathrm{~m}$, or $>100 \mathrm{~m}$ ) and size of the nearest gap, and whether the bird was foraging for himself or feeding fledglings. Some individuals recorded as foraging for themselves may have been foraging for young in the nest; however, the locations of most nests in the study site were known (Moorman et al. 2002) and no birds were observed leaving foraging areas to make trips to nearby nests.

I included only observations for which the bird was in continuous view for at least $20 \mathrm{sec}$. To determine attack rates, I pooled all observations on an individual in the same day at the same distance interval from a gap. Only individuals with at least 1 minute of total observation time were included, and no observation spanned $>1$ hour in duration. To minimize impacts of autocorrelation, no individual was observed on more than four days at the same location. Although Hooded Warblers frequently used the gaps, all observations were restricted to the forest surrounding gaps because of the difficulty of observing birds for a continuous 20 -sec period in the dense gap vegetation. The species of the substrate plant usually was not noted because Hooded Warblers forage rapidly and change substrates frequently, often using up to five plant species during the course of a 1-min observation and thus confounding efforts to determine plant species-specific attack rates.

\section{STATISTICAL ANALYSES}

I used a split-split plot analysis of variance (ANOVA, Proc GLM; SAS Inst. 1999) to compare arthropod abundance (number of individuals $\mathrm{kg}^{-1}$ of dry foliage) among gap sizes, distances from gaps, and plant species groups, with gap size nested within replicate gaps (plus appropriate interactions; Lentner and Bishop 1986, Weber and Killings 2000). I tested gap size with the mean square error from size-within-replicate gap as the error term, and I tested distance from gap and the size $\times$ distance interaction with the mean square error from size-within-replicate gap $X$ distance as the error term (see Table 2 for structure of ANOVA). I used a similar design, without plant species, to compare Hooded Warbler foraging attack rates among gap sizes and distances from gaps. Additional factors in the model for attack rates included year and a variable indicating whether fledglings were present, because birds feeding fledglings appeared to forage faster than birds foraging for themselves. When ANOVA revealed a significant interaction $(P \leq 0.05)$, I compared the dependent variable among levels of one interacting factor separately for each level of the other interacting factor. I compared means using Tukey's Studentized Range test with appropriate error terms.

I used linear regression to directly assess the relationship between foraging attack rates and arthropod abundance, with arthropod abundance as the independent variable. However, foraging observations were obtained from across the study site, whereas arthropods were sampled at fewer locations. Thus, many foraging observations were not included in this analysis because they lacked arthropod data from the same location, which limited the sample size for the analysis. Though arthropod data were collected only during 1998, I assumed that arthropod abundance at any location was similar over time relative to other locations. For those foraging observations with spatially corresponding arthropod data (i.e., collected in the same distance interval from the same gap), I derived arthropod abundance by averaging the values for the 6 samples from that location ( 3 plant species $\times 2$ samples).

Values reported in the results are means \pm SE.

\section{RESULTS}

Foliage sampling collected 197 individual arthropods representing 9 orders (Table 1). Arthropod abundance (number of arthropods $\mathrm{kg}^{-1}$ dry foliage) did not differ in the forest surrounding gaps of various sizes (0.06-ha gaps: $132.3 \pm$ 32.6; 0.13-ha gaps: $84.8 \pm 20.9$; 0.50-ha gaps: $84.5 \pm 23.4)$, but it differed among plant species groups (Table 2), with abundance being greater $(P<0.05)$ on switchcane $(212.2 \pm 38.1)$ than on red maple $(40.1 \pm 6.6)$ and oaks $(49.3 \pm 7.7)$. Arthropod abundance also differed among various distances from gaps $\left(F_{2,3}=65.9, P<0.01\right)$ : abundance was greater at distances $>100 \mathrm{~m}$ from a gap edge $(166.6 \pm 36.1)$ than at $30-100$ $\mathrm{m}$ from an edge $(90.6 \pm 21.5)$, and was greater at $30-100 \mathrm{~m}$ from an edge than at $0-30 \mathrm{~m}$ from 
TABLE 1. Arthropods collected in foliage-clipping samples in a bottomland hardwood forest in South Carolina, June 1998

\begin{tabular}{lcc}
\hline \hline \multicolumn{1}{c}{ Order } & $\begin{array}{c}\text { Number of } \\
\text { individuals }\end{array}$ & Proportion \\
\hline Araneida & 60 & 0.30 \\
Coleoptera & 39 & 0.19 \\
Homoptera & 36 & 0.18 \\
Lepidoptera & 24 & 0.12 \\
Hemiptera & 17 & 0.08 \\
Orthoptera & 11 & 0.05 \\
Hymenoptera & 6 & 0.03 \\
Diptera & 2 & 0.01 \\
Neuroptera & 2 & 0.01 \\
Total & 197 & 1.00 \\
\hline
\end{tabular}

an edge (44.4 \pm 10.4$)$. However, there was an interaction between plant species and distance from gap (Table 2), so I compared the effect of distance separately for each species. Arthropod abundance did not differ among distances from gap edge for oaks $\left(F_{2,3}=0.4, P=0.72\right)$ and red maple $\left(F_{2,3}=0.8, P=0.52\right)$, but did for switchcane $\left(F_{2,3}=12.0, P=0.04\right.$; Fig. 1$)$.

I obtained 68 foraging observations of $\geq 1$ min duration on $\geq 29$ individual birds. By distance interval from gap, sample size was 17 (0$30 \mathrm{~m}), 30(30-100 \mathrm{~m})$, and $21(>100 \mathrm{~m})$. Attack rates did not differ among years $\left(F_{2,67}=2.1, P\right.$ $=0.14)$ or gap sizes $\left(F_{4,6}=0.4, P=0.82\right.$; Table

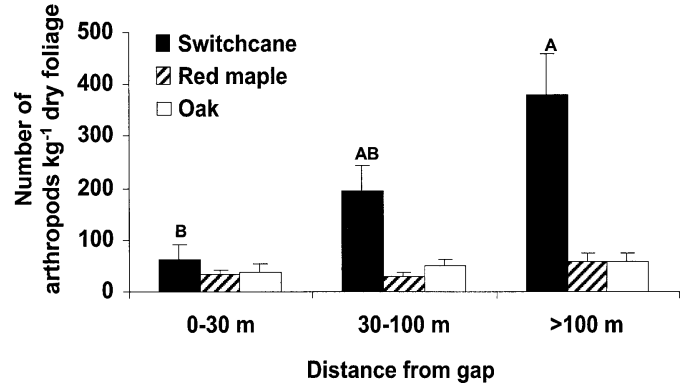

FIGURE 1. Arthropod abundance on three plant species groups at three distances from group-selection harvest gaps in a bottomland hardwood forest in South Carolina during June 1998. Means were compared among distances from gaps only within species, and bars with the same or no letter did not differ.

3 ), so I eliminated these variables from the model. In the reduced model, attack rate did not differ among distances from gaps $\left(F_{2,7}=2.1, P=\right.$ 0.20 ), but there was an interaction between presence of fledglings and distance from gap $\left(F_{2,51}\right.$ $=3.5, P=0.04)$, so I compared attack rates among distances from gaps separately for birds foraging for themselves versus those foraging for fledglings. When foraging for fledglings, attack rate did not differ among distances from gaps $\left(F_{2.5}=0.3, P=0.74\right)$, but when foraging for themselves, attack rates differed among distances $\left(F_{2,6}=5.3, P=0.05\right)$ with rates being lower $(P$

TABLE 2. Analysis of variance table for comparison of arthropod abundance among three sizes of groupselection harvest gaps, three distances from gaps, and three plant species groups in a bottomland hardwood forest in South Carolina, June 1998.

\begin{tabular}{|c|c|c|c|c|}
\hline Source & df & Mean square & $F$ & $P$ \\
\hline \multicolumn{5}{|l|}{ Whole plot } \\
\hline Size $^{\mathrm{a}}$ & 2 & 27282.3 & 3.1 & 0.19 \\
\hline Error: Size $\left(\mathrm{Gap}^{\mathrm{b}}\right)$ & 3 & 8739.2 & 0.6 & 0.64 \\
\hline \multicolumn{5}{|l|}{ Subplot } \\
\hline Distance ${ }^{c}$ & 2 & 137153.3 & 34.3 & $<0.01$ \\
\hline Size $\times$ Distance & 4 & 6775.5 & 1.7 & 0.27 \\
\hline Error: Size $($ Gap $) \times$ Distance & 6 & 4000.8 & 0.3 & 0.95 \\
\hline \multicolumn{5}{|l|}{ Sub-subplot } \\
\hline Species $^{\mathrm{d}}$ & 2 & 337258.1 & 21.8 & $<0.01$ \\
\hline Size $\times$ Species & 4 & 7398.4 & 0.5 & 0.75 \\
\hline Distance $\times$ Species & 4 & 88418.2 & 5.7 & $<0.01$ \\
\hline Size $\times$ Distance $\times$ Species & 8 & 7047.2 & 0.5 & 0.88 \\
\hline Error & 72 & 15473.7 & & \\
\hline
\end{tabular}

a Size $=$ gap size $(0.06,0.13$, and 0.50 ha).

${ }^{\mathrm{b}} \mathrm{Gap}=$ replicate gap.

${ }^{\mathrm{c}}$ Distance $=$ distance from gap edge $(0-30,30-100$, and $>100 \mathrm{~m})$.

d Species = plant species group: oaks (Quercus alba, Q. michauxii), red maple (Acer rubrum), switchcane (Arundinaria gigantea). 
TABLE 3. Analysis of variance table for comparison of foraging attack rates of Hooded Warblers among sizes of group-selection harvest gaps, distances from gaps, and whether birds were foraging for themselves or for fledglings in a bottomland hardwood forest in South Carolina, 1996-1998.

\begin{tabular}{lcccc}
\hline \hline \multicolumn{1}{c}{ Source } & df & Mean square & $F$ & $P$ \\
\hline Whole plot $^{\text {a }}$ & & & & \\
$\quad$ Size $^{\mathrm{a}}$ & 4 & 0.35 & 0.4 & 0.82 \\
$\quad$ Error: Size $\left(\mathrm{Gap}^{\mathrm{b}}\right)$ & 6 & 0.92 & 1.5 & 0.20 \\
Subplot & & & & \\
$\quad$ Distance & 2 & 1.54 & 10.0 & 0.02 \\
$\quad$ Size $\times$ Distance & 6 & 0.44 & 2.9 & 0.13 \\
$\quad$ Error: Size (Gap) $\times$ Distance & 5 & 0.15 & 0.3 & 0.93 \\
Sub-subplot & & & & \\
$\quad$ Feedingd & 1 & 7.40 & 12.3 & $<0.01$ \\
Size $\times$ Feeding & 2 & 0.27 & 0.4 & 0.65 \\
$\quad$ Distance $\times$ Feeding & 2 & 1.13 & 1.9 & 0.17 \\
Size $\times$ Distance $\times$ Feeding & 2 & 1.3 & 2.3 & 0.12 \\
Error & 37 & 0.60 & & \\
\hline
\end{tabular}

${ }^{\text {a }}$ Size $=$ gap size $(0.03,0.06,0.13,0.26$, and 0.50 ha $)$.

$\mathrm{b}$ Gap = replicate gap.

${ }^{\mathrm{c}}$ Distance $=$ distance from gap edge $(0-30,30-100$, and $>100 \mathrm{~m})$.

${ }^{\mathrm{d}}$ Feeding $=$ whether birds were foraging for themselves or feeding fledglings.

$<0.05)$ at distances $0-30 \mathrm{~m}$ from gap edges than $>100 \mathrm{~m}$ from gap edges (Fig. 2). The number of fledglings observed ranged from 1-3.

Nineteen foraging observations had corresponding arthropod abundance data. For these observations, attack rate was positively associated with arthropod abundance $\left(R^{2}=0.25, P=\right.$ 0.03; Fig. 3).

\section{DISCUSSION}

My prediction that arthropod abundance would be greatest near gaps and would decline with distance into the surrounding forest proved incorrect. In fact, the opposite was true; there ap- peared to be a negative edge effect on arthropod abundance, with the lowest numbers occurring near gaps and the highest numbers more than $100 \mathrm{~m}$ into the forest. Information from previous studies of arthropod response to canopy openings is inconsistent. Shure and Phillips (1991) reported lower arthropod abundance in 0.080.4-ha canopy gaps than in the surrounding forest, and Norwood et al. (1995) found fewer individuals of several insect groups in gap understory than forest understory in at least one season. Conversely, Helle and Muona (1985) reported that forest invertebrate numbers were greater near a clearcut edge, and Heliölä et al.

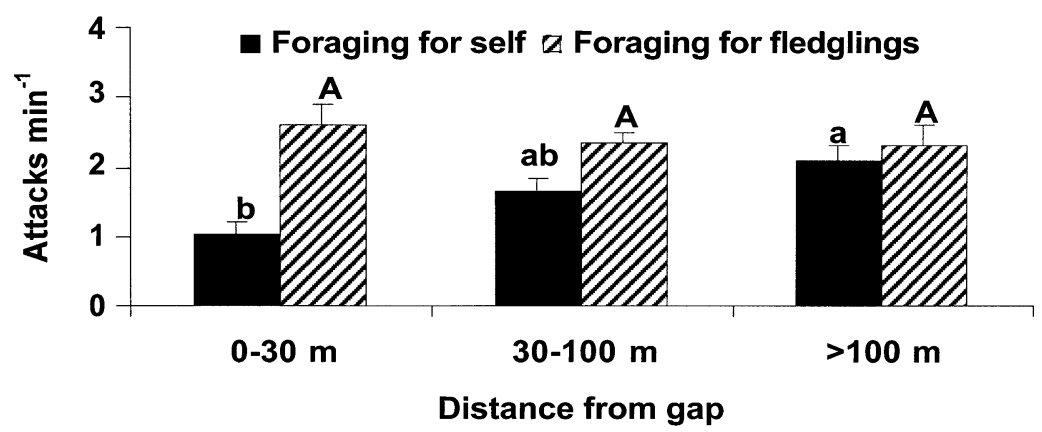

FIGURE 2. Foraging attack rates of Hooded Warblers foraging for themselves and for fledglings (mean \pm SE) at three distances from group-selection harvest gaps in a bottomland hardwood forest in South Carolina during May-June, 1996-1998. Means were compared among distances from gaps separately for birds foraging for themselves (lowercase letters) and for fledglings (uppercase letters), and bars with the same letter did not differ. 


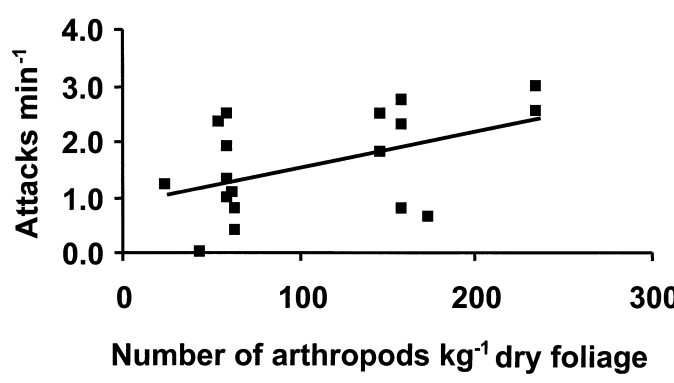

FIGURE 3. Relationship between Hooded Warbler foraging attack rates and arthropod abundance in a bottomland hardwood forest in South Carolina during May-June, 1996-1998.

(2001) found more carabid beetles in a clearcut than in surrounding forest. In a bottomland hardwood forest in Arkansas, Gorham et al. (1996) reported that only spiders were more abundant in natural canopy gaps than in surrounding forest; all other groups were more abundant in the forest. Although I did not evaluate individual orders of arthropods, more than half $(52 \%)$ of all spiders collected were $>100 \mathrm{~m}$ from a gap edge, suggesting that spiders, like arthropods in general, were negatively impacted by gaps. This data on spider abundance appears to contrast with the findings of Gorham et al. (1996) on spiders. However, since I did not sample within the gaps themselves (only in the surrounding forest), I have no information on the relative abundance of spiders in gaps versus surrounding forest so our data are not comparable. My results indicate that foliage-dwelling arthropods are negatively affected by group-selection harvest gaps in bottomland hardwood forests during early summer.

Hooded Warbler foraging attack rates also were negatively affected by nearby gaps. Although the attack rates of birds foraging for fledglings were not affected by the distance from a gap edge, when birds were foraging for themselves, attack rates were greater at least $100 \mathrm{~m}$ from an edge than they were from 0-30 $\mathrm{m}$ from an edge. This pattern coincided with the abundance of arthropods, and in fact, the two variables were correlated. Several studies have documented relationships between avian foraging and arthropod abundance in forested habitats (see Hutto 1990 for review). Holmes and Schultz (1988) reported that lepidoptera larvae varied in abundance on different tree species and that some bird species foraged in proportion to prey abundance. Similarly, Keane and Morrison (1999) documented that shifts in use of plant species by Black-throated Gray Warblers (Dendroica nigrescens) corresponded to changes in arthropod abundance on those plants. In plots treated with insecticide to control gypsy moths (Lymantria dispar), Red-eyed Vireo (Vireo olivaceous) foraging areas were larger than in untreated plots (Cooper et al. 1990). In contrast, Brown-headed Cowbirds (Molothrus ater) peck rates were not related to invertebrate biomass in Missouri grasslands, although invertebrates were not the sole food source of these birds (Morris and Thompson 1998). Hooded Warblers apparently encountered fewer prey and presumably foraged less efficiently where arthropods were least abundant, i.e., near gaps.

Reduced prey near gaps did not seem to affect Hooded Warbler use of gap habitat and gap edges. A concurrent study showed that Hooded Warblers were no less abundant in forested plots containing gaps than in plots without gaps (Moorman and Guynn 2001). Although no nests were found in gaps during the study period, nest density actually was highest near edges (Moorman et al. 2002). Additionally, I frequently encountered Hooded Warblers singing and foraging in and around gaps. Norris et al. (2000) likewise documented frequent use of forest edges by Hooded Warblers in isolated woodlots in Pennsylvania. In light of the reduced arthropod abundance near gap edges, the use of such edges by Hooded Warblers is puzzling. However, I did not sample within gaps, so patterns of prey abundance in the gaps themselves remain unknown. Even if prey density is low in gaps relative to interior forest (as it is in forested habitat near gaps), the density of plant substrates is much greater in gaps than in forest (Moorman and Guynn 2001). Thus, total prey availability in fact may be greatest in gaps. Hooded Warblers may have used gaps and gap edges to take advantage of exposed perches for singing, enhanced cover for brood rearing (Marshall et al. 2003), and the potentially abundant food resources within gaps.

I found no evidence for an effect of gap size on either abundance of arthropods in the adjacent forest or foraging of Hooded Warblers in the adjacent forest. The lack of an effect on foraging is not surprising in light of the fact that prey abundance was not affected by gap size. Similarly, Moorman and Guynn (2001) reported 
no difference in Hooded Warbler abundance among gap sizes.

Hooded Warblers foraging for fledglings apparently were able to maintain attack rates at a constant level for provisioning, regardless of spatial variation in prey abundance; attack rates for these birds did not differ among distances from gaps. Similarly, Buehler et al. (2002) reported that provisioning of nestlings by Hooded Warblers was not related to arthropod abundance. That provisioning of fledglings did not vary may indicate that prey availability is not limiting at any point across the forest, and when necessary, birds are able to locate sufficient prey anywhere. Conversely, the fact that attack rates of these birds did not differ with prey abundance may indicate that birds near gaps (where prey abundance was lower) were forced to increase their foraging speed (distance per unit time or hops per unit time; Hutto 1990) to remain capable of meeting the provisioning needs of fledglings; the lower the prey density, the faster the birds must forage to maintain a constant attack rate. Whether additional energetic costs were incurred from such an adjustment is unknown. Information on physiological condition and ultimately survival is necessary to adequately determine whether reduced arthropod abundance near gaps results in reduced fitness for Hooded Warblers. However, a reduction in fitness seems unlikely, as the species apparently is adapted to exploit small canopy gaps within mature forests (Evans Ogden and Stutchbury 1994). Further research should address the relationship between avian foraging and arthropod abundance within gaps, as compared to the surrounding forest, and should consider these dynamics during postbreeding and migration periods.

\section{ACKNOWLEDGMENTS}

Funding for this study was provided by the U.S. Department of Energy-Savannah River through the U.S. Forest Service-Savannah River and the U.S. Forest Service Southern Research Station under Interagency Agreement DE-AI09-00SR22188. Additional funding was provided by The University of Georgia and by a USDA/CSREES National Research Initiative Competitive Grant (No. 93-37101-8662) to W. P. Smith and B. S. Collins. I thank W. F. Moore and J. Boze for assistance with foraging observations, B. Higerd and J. Boze for assistance with arthropod sampling and identification, and R. J. Cooper and C. E. Moorman for reviewing the manuscript. I am especially indebted to R. J. Cooper for advice on statistical analysis. This study benefitted throughout from the invaluable insights and support of C. E. Moorman.

\section{LITERATURE CITED}

Bowen, L. T. 2004. Seasonal relationships between birds and arthropods in bottomland forest canopy gaps. Ph.D. dissertation, North Carolina State University, Raleigh, NC.

Blake, J. G., AND W. G. Hoppes. 1986. Resource abundance and microhabitat use by birds in an isolated east-central Illinois woodlot. Auk 103:328-340.

Buehler, D. M., D. R. Norris, B. J. M. Stutchbury, AND N. C. Kopysh. 2002. Food supply and parental feeding rates of Hooded Warblers in forest fragments. Wilson Bulletin 114:122-127.

Buffington, J. M., J. C. Kilgo, R. A. Sargent, K. V. Miller, And B. R. Chapman. 2000. Foraging behavior of three passerines in mature bottomland hardwood forests during summer. Journal of Elisha Mitchell Scientific Society 116:356-359.

Castleberry, S. B., W. M. Ford, K. V. Miller, and W. P. SMith. 2000. Influences of herbivory and canopy opening size on forest regeneration in a southern bottomland hardwood forest. Forest Ecology and Management 131:57-64.

Collins, B. S., and L. L. Battaglia. 2002. Microenvironmental heterogeneity and Quercus michauxii regeneration in experimental gaps. Forest Ecology and Management 155:279-290.

Cooper, R. J., K. M. Dodge, P. J. Martinat, S. B. Donahoe, And R. C. Whitmore. 1990. Effect of diflubenzuron application on eastern deciduous forest birds. Journal of Wildlife Management 54: 486-493.

CoOper, R. J., And R. C. Whitmore. 1990. Arthropod sampling methods in ornithology. Studies in Avian Biology 13:29-37.

Evans Ogden, L. J., And B. J. Stutchbury. 1994. Hooded Warbler (Wilsonia citrina). In A. Poole and F. Gill [EDS.], The birds of North America, No. 110. The Academy of Natural Sciences, Philadelphia, PA, and The American Ornithologists' Union, Washington, DC.

Germaine, S. S., S. H. Vessey, and D. E. Capen. 1997. Effects of small forest openings on the breeding bird community in a Vermont hardwood forest. Condor 99:708-718.

Gorham, L. E., B. D. Keeland, S. Mopper, S. L. King, AND K. J. JoHnson. 1996. Effects of canopy gap dynamics on arthropod abundance in a bottomland forest in northeast Arkansas, p. 165-169. In K. M. Flynn [ED.], Proceedings of the southern forested wetlands ecology and management conference. Consortium for Research on Southern Forested Wetlands, Clemson, SC.

HAMEL, P. B. 1989. Breeding bird populations on the Congaree Swamp National Monument, South Carolina, p. 617-628. In R. R. Sharitz and J. W. Gibbons [EDS.], Freshwater wetlands and wildlife. National Technical Information Service, Springfield, VA.

Harrison, C. A., AND J. C. KILGO. 2004. Short-term breeding bird response to two harvest practices in 
a bottomland hardwood forest. Wilson Bulletin 116:314-323.

Heliölä, J., M. KoIvula, AND J. Niemelä. 2001. Distribution of Carabid beetles (Coleoptera, Carabidae) across a boreal forest-clearcut ecotone. Conservation Biology 15:370-377.

Helle, P., AND J. MuONA. 1985. Invertebrate numbers in edges between clear-fellings and mature forests in northern Finland. Silva Fennica 19:281-294.

Hodges, M. F., AND D. G. KREMENTZ. 1996. Neotropical migratory breeding bird communities in riparian forests of different widths along the Altamaha River, Georgia. Wilson Bulletin 108:496506.

Holmes, R. T., AND J. C. Schultz. 1988. Food availability for forest birds: effects of prey distribution and abundance on bird foraging. Canadian Journal of Zoology 66:720-728.

HutTo, R. L. 1990. Measuring the availability of food resources. Studies in Avian Biology 13:20-28.

KeAne, J. J., AND M. L. MorRison. 1999. Temporal variation in resource use by Black-throated Gray Warblers. Condor 101:67-75.

Kilgo, J. C., R. A. Sargent, B. R. Chapman, and K. V. Miller. 1996. Nest-site selection by Hooded Warblers in bottomland hardwoods of South Carolina. Wilson Bulletin 108:53-60.

Kilgo, J. C., R. A. Sargent, B. R. Chapman, and K. V. Miller. 1998. Effect of stand width and adjacent habitat on breeding bird communities in bottomland hardwoods. Journal of Wildlife Management 62:72-83.

Kilgo, J. C., K. V. Miller, and W. P. Smith. 1999. Effects of group selection timber harvest in bottomland hardwoods on fall migrant birds. Journal of Field Ornithology 70:404-413.

Lentner, M., AND T. Bishop. 1986. Experimental design and analysis. Valley Book Co., Blacksburg, VA.

LEVEY, D. J. 1988. Tropical wet forest treefall gaps and distributions of understory birds and plants. Ecology 69:1076-1089.

LovetTe, I. J., AND R. T. Holmes. 1995. Foraging behavior of American Redstarts in breeding and wintering habitats: implications for relative food availability. Condor 97:782-791.

Majer, J. D., H. F. Recher, W. S. Perriman, and N. ACHUTHAN. 1990. Spatial variation of invertebrate abundance within the canopies of two Australian eucalypt forests. Studies in Avian Biology 13:6572.

Marshall, M. R., J. A. DeCecco, A. B. Williams, G. A. Gale, AND R. J. CoOper. 2003. Use of regenerating clearcuts by late-successional bird species and their young during the post-fledging period. Forest Ecology and Management 183:127-135.

Martin, T. E., AND J. R. KARR. 1986. Patch utilization by migrating birds: resource oriented? Ornis Scandanavica 17:165-174.

Mitchell, L. J., AND R. A. Lancia. 1990. Breeding bird community changes in bald-cypress-tupelo wetland following timber harvesting. Proceedings of the annual conference of the Southeastern As- sociation of Fish and Wildlife Agencies 44:189201.

Moorman, C. E., And D. C. GuYnN. 2001. Effects of group-selection opening size on breeding bird habitat use in a bottomland forest. Ecological Applications 11:1680-1691.

Moorman, C. E., D. C. GuYnN, AND J. C. Kilgo. 2002. Hooded Warbler nesting success adjacent to group-selection and clearcut edges in a southeastern bottomland forest. Condor 104:366-377.

Morris, D. L., AND F. R. ThOMPSON III. 1998. Effects of habitat and invertebrate density on abundance and foraging behavior of Brown-headed Cowbirds. Auk 115:376-385.

Norris, D. R., B. J. M. Stutchbury, AND T. E. PitchER. 2000. The spatial response of male Hooded Warblers to edges in isolated fragments. Condor 102:595-600.

Norwood, C., G. Wardell-Johnson, J. D. Majer, And M. WILLIAMS. 1995. Short-term influences of edge and gap creation on bird populations in jarrah forest, western Australia. Australian Forestry 58:4857.

Pashley, D. N., AND W. C. Barrow. 1993. Effects of land use practices on Neotropical migratory birds in bottomland hardwood forests, p. 315-320. In D. M. Finch and P. W. Stangel [EDS.], Status and management of Neotropical migratory birds. U.S. Forest Service General Technical Report RM-229.

Robinson, S. K., ANd R. T. Holmes. 1984. Effects of plant species and foliage structure on the foraging behavior of forest birds. Auk 101:672-684.

Rodenhouse, N. L., P. J. Bohlen, AND G. W. Barrett. 1997. Effects of woodland shape on the spatial distribution and density of 17-year periodical cicadas (Homoptera: Cicadidae). American Midland Naturalist 137:124-135.

Sallabanks, R., J. F. Walters, and J. A. Collazo. 2000. Breeding bird abundance in bottomland hardwood forests: habitat, edge, and patch size effects. Condor 102:748-758.

SAS InstituTE. 1999. SAS/STAT user's guide, release 8.01. SAS Institute Inc., Cary, NC.

Schemske, D. W., AND N. BROKAW. 1981. Treefalls and the distribution of understory birds in a tropical forest. Ecology 62:938-945.

Schowalter, T. D. 1985. Adaptations of insects to disturbance, p. 235-252. In S. T. A. Pickett and P. S. White [EDS.], The ecology of natural disturbance and patch dynamics. Academic Press, Inc., Orlando, FL.

Shure, D. J., AND D. L. PhILliPs. 1991. Patch size of forest openings and arthropod populations. Oecologia 86:325-334.

Smith, R., And M. Dallman. 1996. Forest gap use by breeding Black-throated Green Warblers. Wilson Bulletin 108:588-591.

Weber, D. C., AND J. H. Killings. 2000. A first course in the design of experiments: a linear models approach. CRC Press, Washington, DC.

White, T. C. R. 1984. The abundance of invertebrate herbivores in relation to the availability of nitrogen in stressed food plants. Oecologia (Berlin) 63: 90-105. 
Wigley, T. B., AND T. H. RoBerTs. 1997. Landscapelevel effects of forest management on faunal diversity in bottomland hardwoods. Forest Ecology and Management 90:141-154.

Workman, S. W., AND K. W. MCLeod. 1990. Vegetation of the Savannah River Site: major community types. Publication SRO-NERP-19, National En- vironmental Research Park Program. Savannah River Ecology Laboratory, Aiken, SC.

Wunderle, J. M., JR., A. Diaz, I. VelazQuez, AND R. SCHORRON. 1987. Forest openings and the distribution of understory birds in a Puerto Rican rainforest. Wilson Bulletin 99:22-37. 